\section{Drying and Shade Effects on Spearmint Oil Yields and Composition}

\author{
Valtcho D. Zheljazkov ${ }^{1}$ \\ University of Wyoming, Sheridan Research and Extension Center, 663 \\ Wyarno Road, Sheridan, WY 82801
}

Tess Astatkie

Dalhousie University, Faculty of Agriculture, 50 Pictou Road, P.O. Box 550, Truro, Nova Scotia B2N 5E3, Canada

\section{Ekaterina Jeliazkova}

University of Wyoming, Sheridan Research and Extension Center, 663 Wyarno Road, Sheridan, WY 82801

Additional index words. carvone, drying, essential oil composition, essential oil content, Mentha spicata, shade and sun

\begin{abstract}
Native' spearmint (Mentha spicata L.) is one of the two most widely grown spearmints in the United States and in other countries. Recent studies demonstrated the feasibility of growing 'Native' spearmint as a cash crop for north-central Wyoming. Transportation and energy costs of commercial mint production can be reduced by drying the spearmint in windrows in the field for a few days after harvest and before oil extraction. This method of drying mint has been a common practice in the traditional mint production regions of the world. However, there is a knowledge gap regarding the effect of this drying method on the yield and composition of 'Native' spearmint oil. Field and laboratory experiments were conducted in Wyoming to evaluate the effects of drying duration in days after harvest (DAH: $0,1,2,3,4,7$, or 11) and drying conditions (shade and sun) on the yield of essential oil (EO) and on the concentrations of different oil constituents (beta-pinene, myrcene, limonene, eucalyptol, cis-sabinene hydrate, 4terpineol, cis-dihydro carvone, cis-carveol, carvone, iso-dihydro carveol acetate, betabourbonene, beta-caryophyllene, alpha-humulene/transbeta-farnesene, and germacrene D). Neither drying duration nor drying condition had a significant effect on oil yield. The average yield of essential oil was $0.25 \mathrm{~g}$ of oil per $100 \mathrm{~g}$ of fresh weight. Drying duration and drying conditions had a significant effect on the composition of EOs. The concentrations of myrcene and germacrene-D were higher in the EOs from plants dried under shade $(3.2 \%$ and $2.4 \%$, respectively) than the EOs from plants dried under direct sun (3\% and $2.2 \%$, respectively). The concentration of beta-pinene was higher in plants dried under direct sun than under shade $(0.92 \%$ vs. $0.88 \%)$. Carvone ranged from $51 \%$ to $53 \%$ in the oil and was higher in EOs from plants dried for 1 and 2 DAH and lower in EOs from plants dried for 7 days. Drying of 'Native' spearmint under direct sun in Wyoming for up to $11 \mathrm{DAH}$ can be used as an effective tool to reduce transportation and energy costs without affecting oil yields.
\end{abstract}

The United States is a major producer of EO from peppermint (Mentha $\times$ piperita L.) and spearmints such as 'Native' spearmint (Mentha spicata L.) and 'Scotch' spearmint (Mentha $\times$ gracilis Sole.; syn. M. cardiaca L.) [Lawrence, 2006; Mint Industry Research Council, 2012; National Agricultural Statistics

Received for publication 25 Nov. 2013. Accepted for publication 24 Dec. 2013.

This research was funded in part by the 2011 SunGrant Initiative Program grant and by the University of Wyoming Outreach School funds awarded to Dr. Valtcho Jeliazkov (Zheljazkov).

We thank Mr. Bradley Wood and Ms. Sydney Waggener for their help with the field trials and the oil extraction. We thank Dr. Ami Erickson and Dr. Alex Martynenko for their critical review of the manuscript.

${ }^{1}$ To whom reprint requests should be addressed; e-mail vjeliazk@uwyo.edu or Valtcho.pubs@gmail. com. concentration in the oil ranging between $42 \%$ and $75 \%$ depending on the timing of harvesting after the first fall frosts (Zheljazkov et al., 2013). In studies conducted in Mississippi with the same cultivar of spearmint, the carvone concentration was $36 \%$ to $63 \%$ in the oil of freshly distilled biomass and $45 \%$ to $62 \%$ in the oil of dried biomass at different harvesting times (Zheljazkov et al., 2010b). In another study conducted in Mississippi with the same cultivar of spearmint, the oil content in the fresh biomass was $0.18 \%$ to $0.19 \%$, whereas the concentration of carvone in the oil varied between 68 and $74 \%$ (Zheljazkov et al., 2010a).

In the spearmint and peppermint production industry, transportation and energy are significant components of the total cost. To decrease both transportation and energy costs associated with production and distillation (the extraction of the EO), commercial mint producers have been drying the spearmint in windrows in the field for 2 to $7 \mathrm{DAH}$ and before oil extraction. Drying reduces moisture content of harvested biomass, decreasing the biomass weight three to four times relative to the weight of fresh herbage at harvest. Hence, both transportation and the energy costs associated with the distillation are reduced. As a result of the reduced moisture content, more dried biomass can be fitted into the distillation units relative to the fresh herbage biomass, which increases efficiency of distillation. However, there is a knowledge gap regarding the effect of drying on 'Native' spearmint oil yields and composition. There have been some previous studies on the effect of different drying methods (oven-drying, freeze-drying, and air-drying) on spearmint flavor and oil composition (Díaz-Maroto et al., 2003). However, this is not how the mint industry is drying spearmints or peppermints before oil extraction. Zheljazkov et al. (2010b) reported oil compositional differences between oils extracted from dried vs. fresh biomass of the same cultivar of spearmint harvested at different times (and developmental stages). However, neither of these studies provided insight on how drying duration and drying condition (shade and sun) affect the essential oil yield and composition of 'Native' spearmint. Therefore, the objective of this study was to determine the effects of drying duration in $\operatorname{DAH}(0,1,2,3,4,7$, and 11 ) and drying condition (shade and sun) on the EO yield and on the concentrations of 47 major and minor constituents in the oil.

\section{Materials and Methods}

Field and laboratory experiments. The field and laboratory experiments were conducted in 2012 at the Sheridan Research and Extension Center Experimental Fields at latitude $44^{\circ} 45^{\prime} 686^{\prime \prime} \mathrm{N}$ and longitude $-106^{\circ} 55^{\prime} 479^{\prime \prime} \mathrm{W}$, elevation $1171 \mathrm{~m}$ above sea level. The plantation with 'Native' spearmint was established in 2011 using certified virus-free 'Native' spearmint transplants from Summit Plant Laboratories, Inc. (Fort Collins, CO). The tissue culture propagation of the plant material ensures that all individual plants have the same genotype and are free of viral diseases. 
Land preparation, planting, fertilization, and irrigation. Land preparation and transplanting were carried out as described earlier (Zheljazkov et al., 2012, 2013). Raised beds were prepared with a press-pan-type bedshaper machine. Spearmint transplants (10 to $12 \mathrm{~cm}$ tall) were transplanted at in-row and between-row spacing of $30 \mathrm{~cm}$ in an offset pattern. Transplanting was done in the spring of 2011; this study was conducted in 2012 on a 2-year well-established spearmint plantation. Sinbar (Terbacil 80\% WP; DuPont, Wilmington, DE) at the rate of $2 \mathrm{~kg} \cdot \mathrm{ha}^{-1}$ was applied for weed control before transplanting and incorporated through irrigation. This herbicide is traditionally used in spearmint and peppermint production fields across the United States and worldwide (Lawrence, 2006; Mint Industry Research Council, 1967). Additionally, spearmint plots were handweeded twice to remove weeds unaffected by the applied herbicide. Irrigation was provided through a low-pressure drip-tape system calculated to deliver $2.5 \mathrm{~cm}$ water/week $\left(0.2 \mathrm{~mm}\right.$, emitters spaced at $30 \mathrm{~cm}, 1703 \mathrm{~cm}^{3} /$ $\mathrm{min} / 30.5 \mathrm{~m}$ ). Nitrogen (ammonium nitrate) was surface-applied by sidedressing when plants were 10 to $12 \mathrm{~cm}$ tall at $180 \mathrm{~kg}$ nitrogen/ha.

Harvesting and drying. All samples were obtained on 16 July 2012 by harvesting the flowering spearmint plants at 4 to $5 \mathrm{~cm}$ above the soil surface using a hedge trimmer. Fortytwo 1-kg fresh spearmint biomass samples were generated $(7 \mathrm{DAH} \times$ two drying conditions $\times$ three replications). The fresh spearmint samples were dried either in direct sun or in a shady place (in a well-ventilated barn) until the oil was extracted.

The spearmint samples were distilled at the following DAH: 0 (distillated $3 \mathrm{~h}$ after harvest on the same day), 1, 2, 3, 4, 7, and 11 DAH. During this 11-d period, the night air temperatures fluctuated between 11 and $19{ }^{\circ} \mathrm{C}$. The daytime temperatures during this period were between 29 and $37{ }^{\circ} \mathrm{C}$. Also during this $11-\mathrm{d}$ period, there was $24 \mathrm{~mm}$ of rain on 17 July (1 DAH) and $1 \mathrm{~mm}$ on 18 July (2 DAH). Samples that were drying under direct sun were not protected from the rain to simulate the drying process out in the field as is done by the growers in the mint production industry.

Distillation. All 42 samples were extracted using steam distillation in 2-L steam distillation units for $60 \mathrm{~min}$ (Gawde et al., 2009; Zheljazkov et al., 2010a, 2010b). The resulting essential oil samples were separated from water by draining the water before collecting the EO in glass vials, measured on an analytical scale and kept in a freezer at $-14{ }^{\circ} \mathrm{C}$ until analyzed. The EO content was calculated as grams of oil per $100 \mathrm{~g}$ of fresh herbage (corrected for moisture oil content by taking into consideration the moisture content of various samples). The weight of all samples (originally $1 \mathrm{~kg}$ of fresh material) was taken again just before distillation and water loss was calculated. This difference (between the fresh weight and the weight before distillation) was used to correct the EO content for moisture.
Gas chromatography of spearmint essential oils. The spearmint EO samples were analyzed for chemical profile on a Hewlett Packard (Hewlett-Packard, Palo Alto, CA) gas chromatograph (GC) Model 6890. The carrier gas was helium, $40 \mathrm{~cm} / \mathrm{sec}, 11.7 \mathrm{psi}$ $\left(60{ }^{\circ} \mathrm{C}\right), 2.5 \mathrm{~mL} / \mathrm{min}$ constant flow rate; the injection was split $60: 1$ with $0.5 \mu \mathrm{L}$, the injector temperature was $220^{\circ} \mathrm{C}$; the oven temperature program was $60^{\circ} \mathrm{C}$ for $1 \mathrm{~min}$ and $10^{\circ} \mathrm{C} / \mathrm{min}$ to $250^{\circ} \mathrm{C}$. The GC column was HP-INNOWAX (Agilent Technologies, Santa Clara, CA) (the column was crosslinked polyethylene glycol; $30 \mathrm{~m} \times 0.32 \mathrm{~mm} \times 0.5 \mu \mathrm{m}$ ), and the flame ionization detector (FID) temperature was $275^{\circ} \mathrm{C}$.

Identification of different oil constituents. The identification of individual peaks was done using internal standards (for all the major constituents) by retention time and also using mass spectroscopy (MS). The constituents identified on MS were beta-pinene, myrcene, limonene, eucalyptol, cis-sabinene hydrate, 4-terpineol, cis-dihydro carvone, cis-carveol, carvone, iso-dihydro carveol acetate, beta-bourbonene, beta-caryophyllene, and germacrene D. Of the 47 oil constituents identified (Table 1), we selected the 14 with the highest concentration (beta-pinene, myrcene, limonene, eucalyptol, cis-sabinene hydrate, 4-terpineol, cis-dihydro carvone, cis-carveol, carvone, iso-dihydro carveol acetate, beta-bourbonene, beta-caryophyllene, alpha-humulene/transbeta-farnesene, and germacrene D) for statistical analyses and report.

Statistical analysis. The effects of drying duration $(0,1,2,3,4,7$, and $11 \mathrm{DAH})$ and drying condition (shade and sun) on EO content and the concentrations of beta-pinene, myrcene, limonene, eucalyptol, cis-sabinene hydrate, 4-terpineol, cis-dihydro carvone, cis-carveol, carvone, iso-dihydro carveol acetate, beta-bourbonene, beta-caryophyllene, alpha-humulene/transbeta-farnesene, and germacrene $\mathrm{D}$ were determined using a seven $\times$ two factorial design (Montgomery, 2013) with three replications. The analysis of variance of all these response measurements was completed using the GLM Procedure of SAS (SAS Institute Inc., 2010). When the interaction effect is significant $(P<0.05)$, the significance of the main effects was ignored and multiple means comparison was completed by comparing the least squares means of the corresponding 14 (seven $\times$ two) treatment combinations at the $1 \%$ level of significance to protect the Type I experimentwise error rate from overinflation resulting from the relatively large number of means being compared. However, when the interaction effect is not significant, multiple means comparison of the significant main effect was completed by comparing the least squares means of the $7 \mathrm{DAH}$ and/or the two drying conditions at the $5 \%$ level of significance. The effects that required these multiple means comparison are shown as $*$ or $* *$ in Table 2 . For each response variable, the validity of normal distribution and constant variance model assumptions was verified by examining the residuals as described in Montgomery (2013).

Correlation analysis was also completed to determine the type (positive or negative) and the strength of the relationships among EO content and the concentrations of the constituents.

Table 1. Concentration ranges of the 47 oil constituents in percent of total oil.

\begin{tabular}{|c|c|c|c|}
\hline Constituent & Range (\%) & Constituent & Range (\%) \\
\hline Beta-pinene & $0.80-1.03$ & Beta-copaene & $0.21-0.33$ \\
\hline Myrcene & $2.58-3.91$ & Gamma-terpinene & $0.21-0.73$ \\
\hline Limonene & $10.25-14.86$ & 3-Octanol acetate & $0.27-0.46$ \\
\hline Eucalyptol & $1.14-1.87$ & $\begin{array}{l}\text { Dihydro carveol (and-or) } \\
\text { Transdihydro carvone }\end{array}$ & $0.28-0.70$ \\
\hline Cis-sabinene hydrate & $1.11-3.35$ & Trans-carveol & $0.28-0.71$ \\
\hline 4-terpineol & $0.29-1.23$ & Viridifloral (and-or) Globulol & $0.41-0.89$ \\
\hline Cis-dihydro carvone & $1.48-3.41$ & Trans-carvyl acetate & $0.44-0.87$ \\
\hline Cis-carveol & $4.25-7.14$ & Cis-jasmone & $0.56-0.78$ \\
\hline Carvone & $49.78-54.85$ & Sabinene & $0.62-0.80$ \\
\hline $\begin{array}{l}\text { Iso-dihydro carveol } \\
\text { acetate }\end{array}$ & $0.46-1.32$ & 3-octanol & $0.62-0.94$ \\
\hline Beta-bourbonene & $1.86-3.10$ & Alpha-pinene & $0.88-0.67$ \\
\hline Beta-caryophyllene & $1.67-2.42$ & 2-ethyl furan; Ethyl-2-methyl butyrate & $N^{z}-0.03$ \\
\hline $\begin{array}{l}\text { Alpha-humulene/trans } \\
\text { beta-farnesene }\end{array}$ & $1.07-1.42$ & Pinocarvone & ND- 0.07 \\
\hline Germacrene D & $1.91-2.83$ & Para-cymene; Transpinocarveol & ND-0.08 \\
\hline Terpinolene & $0.10-0.24$ & 2-methyl butyl-2-methyl butyrate & ND-0.09 \\
\hline Trans-ocimene & $0.10-0.30$ & Eugenol & ND-0.09 \\
\hline Alpha-terpinene & $0.11-0.44$ & $\begin{array}{l}\text { Alpha-thujene; 1-octanal/Delta-2-carene; } \\
\text { Translimonene oxide; Transverbenol; } \\
\text { alpha-copaene; germacrene A }\end{array}$ & ND- 0.10 \\
\hline Alpha-terpineol & $0.14-0.20$ & Cis-carvone oxide & $\mathrm{ND}-0.12$ \\
\hline Piperitone & $0.14-0.23$ & Cis-3-hexenol & ND- 0.13 \\
\hline Gamma-muurolene & $0.15-0.22$ & Trans-2-hexanal & ND-0.14 \\
\hline Delta-terpineol & $0.16-0.19$ & Methyl-2-methyl butyrate & ND- 0.15 \\
\hline Trans-sabinene hydrate & $0.17-0.24$ & Trans-carvone oxide & ND- 0.20 \\
\hline Cis-ocimene & $0.19-0.34$ & Caryophyllene oxide & ND- 0.28 \\
\hline $\begin{array}{l}\text { Trans-jasmone/ } \\
\text { beta- elemene }\end{array}$ & $0.21-0.29$ & & \\
\hline
\end{tabular}

${ }^{\mathrm{z}} \mathrm{ND}=$ not detected. 


\section{Results and Discussion}

The main and interaction effects of drying duration and drying condition on essential oil yield and composition. Drying duration had a significant effect on the concentrations of beta-pinene, 4-terpineol, carvone, isodihydro carveol acetate, alpha-humulene/ transbeta farnesene, and germacrene D regardless of drying condition (no significant interaction) (Table 2). Drying conditions (sun or shade) had a significant main effect on the concentrations of beta-pinene, myrcene, and germacrene $\mathrm{D}$, whereas the interaction of drying duration and drying condition was significant on the concentrations of limonene, eucalyptol, cis-sabinene hydrate, cisdihydro carvone, beta-bourbonene, and beta-caryophyllene (Table 2). Neither drying duration nor drying condition affected essential oil content $(0.254 \%$ average in fresh herbage) or the concentration of cis-carveol in the oil (5.96\% average).

Effect of drying duration and drying conditions on the concentration of oil constituents. Drying of the spearmint biomass under direct sun increased the concentration of beta-pinene but reduced the concentrations of myrcene and germacrene $\mathrm{D}$ in the oil relative to drying under shade (Table 3). The concentration of beta-pinene in the oil was low at 0 DAH (distilled the same day after $3 \mathrm{~h}$ ) and higher at 3, 7, and 11 DAH (Table 3). The concentration of carvone, the main oil constituent, was higher in the oil at 1 or $2 \mathrm{DAH}$ than at $7 \mathrm{DAH}$ and not significantly different from that at $0,3,4$, and $11 \mathrm{DAH}$. The concentration of iso-dihydro carveol acetate was high in the oil at $0 \mathrm{DAH}$ but only higher than DAH 1 and 2 and similar to the other DAHs. The combined concentrations of alpha-humulene/transbeta-farnesene were low in the oil at $0 \mathrm{DAH}$ and increased in the oils from 2 to $11 \mathrm{DAH}$. The concentration of germacrene $\mathrm{D}$ was lower in the oil at 0 DAH than at 2, 4, and 11 DAH (Table 3).

Interaction effect of drying duration and drying conditions on the concentration of oil constituents. The concentration of limonene in the oil was highest at $0 \mathrm{DAH}$ and lowest at 11 DAH under sun (Table 4). Conversely, the concentration of eucalyptol was low in the oil at $0 \mathrm{DAH}$ and higher in the oil at $11 \mathrm{DAH}$ under sun (Table 4). The concentration of cissabinene hydrate was low in the oils at $0 \mathrm{DAH}$ and high at 4 to $11 \mathrm{DAH}$ under shade and at 11 DAH under sun (Table 4). The concentration of beta-bourbonene was low in the oils at $0 \mathrm{DAH}$ and increased with increasing drying period under sun but not under shade to reach a maximum concentration in the oil at 11 DAH under sun (Table 4). The concentration of beta-caryophyllene ( $1.71 \%$ to $2.26 \%$ range) was also low in the oils at 0 DAH and generally increased with increasing drying period to reach a maximum concentration in the oil at 11 DAH under sun (Table 4).

Correlation coefficients and types of relationships among essential oil content and the concentrations of the 14 constituents. The EO content was positively correlated to the concentrations of limonene, cis-carveol, and carvone and negatively correlated to the concentrations of eucalyptol, cis-sabinene hydrate, cis-dihydrocarvone, iso-dihydrocarveol-acetate, beta-bourbonene, beta-caryophyllene, and to alfa-humulene/transbeta-farnesene (Table 5). The concentration of beta-pinene in the oil was positively correlated to the concentrations

of eucalyptol, beta-bourbonene, and betacaryophyllene and negatively correlated to the concentrations of cis-carveol and carvone. Myrcene was positively correlated to 4terpineol, cis-dihydro carvone, and iso-dihydro carveol and negatively to cis-sabinene hydrate, cis-carveol, beta-bourbonene, and betacaryophyllene. Limonene was negatively

Table 2. The main and interaction effects of drying duration (DAH) and drying condition (Drying) on essential oil (EO) content and the concentrations of beta-pinene, myrcene, limonene, eucalyptol, cissabinene hydrate, 4-terpineol, cis-dihydro carvone, cis-carveol, carvone, iso-dihydro carveol acetate, beta-bourbonene, beta-caryophyllene, alpha-humulene/transbeta-farnesene, and germacrene D.

\begin{tabular}{lccc}
\hline & \multicolumn{2}{c}{ ANOVA $P$ values for } \\
\cline { 2 - 4 } EO content and constituents & DAH & Drying & DAH*drying \\
\hline EO content & $\mathrm{NS}^{z}$ & NS & NS \\
Beta-pinene & $* * z$ & $* *$ & NS \\
Myrcene & $\mathrm{NS}$ & $* *$ & $*$ \\
Limonene & $\mathrm{NS}$ & $\mathrm{NS}$ & $* *$ \\
Eucalyptol & $\mathrm{NS}$ & $\mathrm{NS}$ & $*$ \\
Cis-sabinene hydrate & $\mathrm{NS}$ & $\mathrm{NS}$ & $*$ \\
4-terpineol & $* *$ & $\mathrm{NS}$ & $\mathrm{NS}$ \\
Cis-dihydro carvone & $\mathrm{NS}$ & $\mathrm{NS}$ \\
Cis-carveol & $\mathrm{NS}$ & $\mathrm{NS}$ & $\mathrm{NS}$ \\
Carvone & $*$ & $\mathrm{NS}$ & $* *$ \\
Iso-dihydro carveol acetate & $*$ & $\mathrm{NS}$ & $*$ \\
Beta-bourbonene & $\mathrm{NS}$ & $\mathrm{NS}$ & $\mathrm{NS}$ \\
Beta-caryophyllene & $\mathrm{NS}$ & $\mathrm{NS}$ & $\mathrm{NS}$ \\
Alpha-humulene/transbeta-farnesene & $* *$ & $\mathrm{NS}$ & $* *$ \\
Germacrene D & $*$ & & \\
\hline
\end{tabular}

${ }_{\mathrm{NS}}=$ Either the effect is nonsignificant $(P>0.05)$ or its significance is ignored because the interaction effect is significant.

$*$, ** Significant at $\alpha=5 \%, 1 \%$, respectively, and require multiple means comparison.

$\mathrm{ANOVA}=$ analysis of variance.

Table 3. Mean beta-pinene, myrcene, carvone, iso-dihydro carveol acetate, alpha-humulene/transbetafarnesene, and germacrene D from the two drying conditions and/or the $7 \mathrm{~d}$ after harvest (DAH).

\begin{tabular}{|c|c|c|c|c|c|c|}
\hline Factor & Beta-pinene & Myrcene & Carvone & $\begin{array}{c}\text { Iso-dihydro } \\
\text { carveol acetate }\end{array}$ & $\begin{array}{l}\text { Alpha- humulene/ } \\
\text { transbeta-farnesene }\end{array}$ & $\begin{array}{c}\text { Germacrene } \\
\text { D }\end{array}$ \\
\hline \multicolumn{7}{|l|}{ Drying } \\
\hline Shade & $0.881 \mathrm{~b}^{\mathrm{z}}$ & $3.20 \mathrm{a}$ & $52.4 \mathrm{a}$ & $0.877 \mathrm{a}$ & $1.24 \mathrm{a}$ & $2.43 \mathrm{a}$ \\
\hline Sun & $0.921 \mathrm{a}$ & $3.01 \mathrm{~b}$ & $51.9 \mathrm{a}$ & $0.850 \mathrm{a}$ & $1.22 \mathrm{a}$ & $2.22 \mathrm{~b}$ \\
\hline \multicolumn{7}{|l|}{ DAH } \\
\hline 0 & $0.848 \mathrm{c}$ & & $52.6 \mathrm{ab}$ & $1.075 \mathrm{a}$ & $1.10 \mathrm{~b}$ & $2.15 \mathrm{~b}$ \\
\hline 1 & $0.897 \mathrm{bc}$ & & $52.8 \mathrm{a}$ & $0.813 \mathrm{~b}$ & $1.18 \mathrm{ab}$ & $2.26 \mathrm{ab}$ \\
\hline 2 & $0.883 \mathrm{bc}$ & & $52.7 \mathrm{a}$ & $0.758 \mathrm{~b}$ & $1.25 \mathrm{a}$ & $2.41 \mathrm{a}$ \\
\hline 3 & $0.913 \mathrm{ab}$ & & $52.1 \mathrm{ab}$ & $0.867 \mathrm{ab}$ & $1.25 \mathrm{a}$ & $2.32 \mathrm{ab}$ \\
\hline 4 & $0.887 \mathrm{bc}$ & & $51.9 \mathrm{ab}$ & $0.867 \mathrm{ab}$ & $1.29 \mathrm{a}$ & $2.41 \mathrm{a}$ \\
\hline 7 & $0.960 \mathrm{a}$ & & $51.0 \mathrm{~b}$ & $0.842 \mathrm{ab}$ & $1.26 \mathrm{a}$ & $2.32 \mathrm{ab}$ \\
\hline 11 & $0.918 \mathrm{ab}$ & & $51.8 \mathrm{ab}$ & $0.823 \mathrm{ab}$ & $1.29 \mathrm{a}$ & $2.42 \mathrm{a}$ \\
\hline
\end{tabular}

${ }^{\mathrm{z}}$ Factor levels whose means do not share the same letter are significantly different.

Table 4. Mean limonene, eucalyptol, cis-sabinene hydrate, cis-dihydro carvone, beta-bourbonene, and beta-caryophyllene from the 14 combinations of DAH and drying conditions.

\begin{tabular}{clllcccc}
\hline DAH & Drying & Limonene & Eucalyptol & $\begin{array}{c}\text { Cis-sabinene } \\
\text { hydrate }\end{array}$ & $\begin{array}{c}\text { Cis-dihydro } \\
\text { carvone }\end{array}$ & $\begin{array}{c}\text { Beta- } \\
\text { bourbonene }\end{array}$ & $\begin{array}{c}\text { Beta- } \\
\text { caryophyllene }\end{array}$ \\
\hline 0 & Shade & $13.5 \mathrm{a}^{\mathrm{z}}$ & $1.33 \mathrm{de}$ & $1.42 \mathrm{f}$ & $3.05 \mathrm{ab}$ & $1.90 \mathrm{~g}$ & $1.71 \mathrm{f}$ \\
1 & Shade & $12.8 \mathrm{abc}$ & $1.37 \mathrm{cde}$ & $1.71 \mathrm{ef}$ & $2.53 \mathrm{abc}$ & $2.12 \mathrm{efg}$ & $1.94 \mathrm{cde}$ \\
2 & Shade & $12.4 \mathrm{abc}$ & $1.42 \mathrm{bcd}$ & $1.97 \mathrm{cdef}$ & $2.45 \mathrm{abc}$ & $2.14 \mathrm{efg}$ & $1.96 \mathrm{bcde}$ \\
3 & Shade & $12.6 \mathrm{abc}$ & $1.41 \mathrm{cde}$ & $2.13 \mathrm{bcde}$ & $2.60 \mathrm{abc}$ & $2.20 \mathrm{ef}$ & $2.01 \mathrm{bcd}$ \\
4 & Shade & $11.4 \mathrm{bc}$ & $1.54 \mathrm{bc}$ & $2.96 \mathrm{a}$ & $3.23 \mathrm{a}$ & $2.23 \mathrm{def}$ & $1.98 \mathrm{bcd}$ \\
7 & Shade & $12.5 \mathrm{abc}$ & $1.50 \mathrm{bcd}$ & $2.72 \mathrm{ab}$ & $2.67 \mathrm{abc}$ & $2.14 \mathrm{efg}$ & $1.94 \mathrm{cde}$ \\
11 & Shade & $13.3 \mathrm{ab}$ & $1.43 \mathrm{bcd}$ & $2.50 \mathrm{abc}$ & $1.87 \mathrm{c}$ & $2.10 \mathrm{efg}$ & $1.94 \mathrm{cde}$ \\
0 & Sun & $13.8 \mathrm{a}$ & $1.21 \mathrm{e}$ & $1.61 \mathrm{ef}$ & $2.78 \mathrm{abc}$ & $1.96 \mathrm{fg}$ & $1.75 \mathrm{ef}$ \\
1 & Sun & $13.0 \mathrm{abc}$ & $1.46 \mathrm{bcd}$ & $1.79 \mathrm{def}$ & $2.66 \mathrm{abc}$ & $2.11 \mathrm{efg}$ & $1.82 \mathrm{def}$ \\
2 & Sun & $13.0 \mathrm{abc}$ & $1.38 \mathrm{cde}$ & $1.89 \mathrm{def}$ & $2.46 \mathrm{abc}$ & $2.38 \mathrm{cde}$ & $2.02 \mathrm{bcd}$ \\
3 & Sun & $13.4 \mathrm{ab}$ & $1.39 \mathrm{cde}$ & $2.34 \mathrm{bcd}$ & $2.67 \mathrm{abc}$ & $2.49 \mathrm{~cd}$ & $2.03 \mathrm{bcd}$ \\
4 & Sun & $13.2 \mathrm{ab}$ & $1.42 \mathrm{bcd}$ & $2.54 \mathrm{abc}$ & $2.13 \mathrm{bc}$ & $2.58 \mathrm{bc}$ & $2.09 \mathrm{abc}$ \\
7 & Sun & $12.9 \mathrm{abc}$ & $1.61 \mathrm{~b}$ & $2.34 \mathrm{bcd}$ & $2.49 \mathrm{abc}$ & $2.78 \mathrm{ab}$ & $2.17 \mathrm{ab}$ \\
11 & Sun & $11.0 \mathrm{c}$ & $1.82 \mathrm{a}$ & $3.03 \mathrm{a}$ & $2.68 \mathrm{abc}$ & $2.87 \mathrm{a}$ & $2.26 \mathrm{a}$ \\
\hline
\end{tabular}

${ }^{\mathrm{z}}$ Means that do not share the same letter are significantly different.

$\mathrm{DAH}=$ days after harvest. 


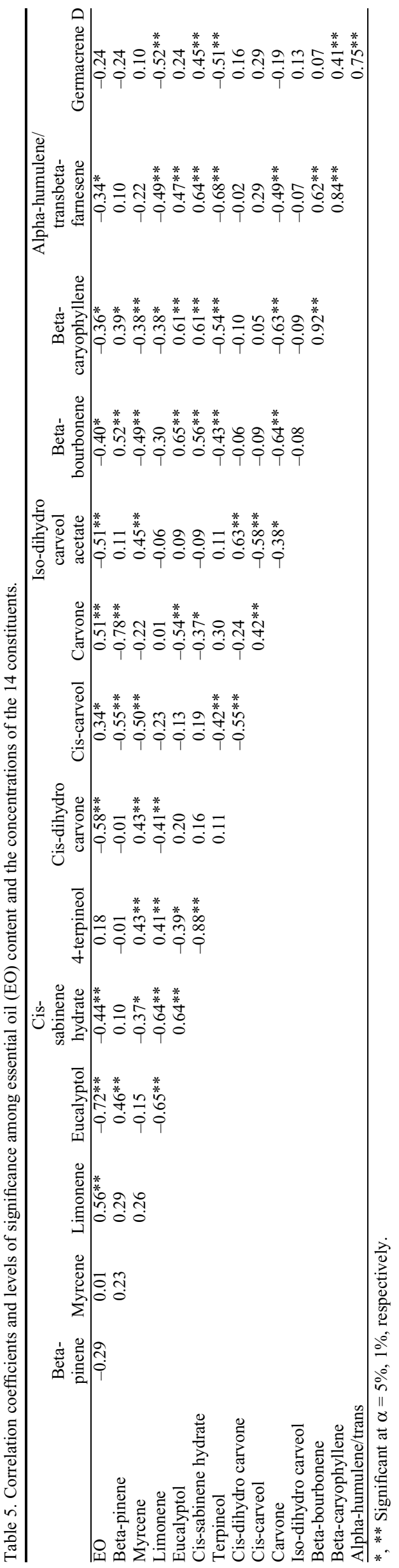

correlated to eucalyptol, cis-sabinene hydrate, cis-dihydro carvone, beta-caryophyllene, alpha-humulene/trans beta-farnesene, and negatively to eucalyptol, cis-sabinene hydrate, cis-dihydro carvone, beta-caryophyllene, alpha-humulene/transbeta-farnesene, and germacrene. Eucalyptol was positively correlated to cis-sabinene hydrate, beta-bourbonene, beta-caryophyllene, and alpha-humulene/ transbeta-farnesene and negatively correlated to 4-terpineol and carvone. Cis-sabinene hydrate was positively correlated to beta-bourbonene, beta-caryophyllene, alpha-humulene/transbetafarnesene, and germacrene D and negatively correlated to 4-terpineol and carvone. Terpineol was negatively correlated to cis-carveol, beta-bourbonene, beta-caryophyllene, alphahumulene/transbeta-farnesene, and germacrene D. Cis-dehydro carvone was positively correlated to iso-dihydro carveol acetate and negatively correlated to cis-carveol. Cis-carveol was positively correlated to carvone and negatively correlated to iso-dihydro carveol acetate. Carvone was negatively correlated to iso-dihydro carveol acetate, beta-bourbonene, beta-caryophyllene, and alpha-humulene/ transbeta-farnesene. Beta-bourbonene was positively correlated to beta-caryophyllene and alpha-humulene/transbeta-farnesene. Beta-caryophyllene was positively correlated to alpha-humulene/transbeta-farnesene and germacrene D. The concentration of alphahumulene/transbeta-farnesene was positively correlated to germacrene D (Table 5).

\section{Concluding Discussion}

In this study the concentration of carvone varied from $51 \%$ to $52.8 \%$, which was within the range reported previously for 'Native' spearmint grown in Wyoming (Zheljazkov et al., 2012, 2013) and other regions in the United States (Murray et al., 1972; Zheljazkov et al., 2010a, 2010b). For example, carvone concentration in the oil of the same cultivar of spearmint reported by Zheljazkov et al. (2013) varied from $51.4 \%$ to $55.9 \%$, whereas carvone concentration in Zheljazkov et al. (2012) varied from $42.9 \%$ to $74.6 \%$. Carvone concentration in this study was also comparable to literature reports from other countries (Bienvenu et al., 1999; Díaz-Maroto et al., 2003; Kizil and Toncer, 2006; Sokovic et al., 2009; Topalov, 1989). Overall, the concentration of carvone in spearmint oils is expected to be above $50 \%$ of the oil (de Carvalho and Da Fonseca, 2006).

Another example was beta-caryophyllene concentration: the concentration of betacaryophyllene in the study of Zheljazkov et al. (2013) varied from $1.5 \%$ to $1.86 \%$, whereas in this study, beta-caryophyllene varied from $1.71 \%$ to $2.26 \%$ depending on the drying period and drying condition.

Our results demonstrated that although the actual EO content (relative to the initial fresh biomass sample) may not change as a function of drying duration (0 to $11 \mathrm{DAH}$ ) or drying conditions (sun or shade), drying would increase the amount of oil obtained from the dried sample as a result of decreased moisture 
in the sample. Therefore, drying may reduce transportation and energy costs associated with distillation of the dried biomass vs. fresh biomass without compromising EO content. Although the duration of drying and the condition of drying significantly affected the concentrations of a number of oil constituents, these alterations were within the range of concentrations for individual oil constituents as reported in the literature for 'Native' spearmint oil. Therefore, these alterations may not affect the overall quality and the market price of the spearmint oil.

\section{Literature Cited}

Bienvenu, F., L. Peterson, and J. Edwards. 1999. Native and Scotch spearmint oil production in Tasmania and Victoria. A report for Rural Industries Research and Development Corporation. Publ. \#99/147, Project \#DAV-101A, p. 32. 11 June 2013. <https://rirdc.infoservices. com.au/downloads/99-147>.

de Carvalho, C.C.C.R. and M.M.R. Da Fonseca. 2006. Carvone: Why and how should one bother to produce this terpene. Food Chem. 95:413422.

Díaz-Maroto, M.C., M.S. Pérez-Coello, M.A. González Viñas, and M.D. Cabezudo. 2003.
Influence of drying on the flavor quality of spearmint (Mentha spicata L.). J. Agr. Food Chem. 51:1265-1269.

Gawde, A.J., C.L. Cantrell, and V.D. Zheljazkov. 2009. Dual extraction of essential oil and podophyllotoxin from Juniperus virginiana. Ind. Crops Prod. 30:276-280.

Kizil, S. and O. Toncer. 2006. Influence of different harvesting times on the yield and oil composition of spearmint (Mentha spicata L. var. spicata). J. Food Agr. Environ. 4:135-137.

Lawrence, B.M. 2006. Mint: The genus Mentha. CRC Press, Boca Raton, FL.

Mint Industry Research Council. 1967. Summary of research conducted with mint industry research council funds in 1967. July 2013. <http:// usmintindustry.org/Portals/1/PDF/ID6411.pdf>.

Mint Industry Research Council. 2012. 11 June 2013. <http://usmintindustry.org/Home/tabid/ 53/Default.aspx $>$.

Montgomery, D.C. 2013. Design and analysis of experiments. 8th Ed. Wiley, New York, NY.

Murray, M.J., W. Faas, and P. Marble. 1972. Effects of plant maturity on oil composition of several spearmint species grown in Indiana and Michigan. Crop Sci. 12:723-728.

National Agricultural Statistics Service. 2009 11 June 2013. <http://www.nass.usda.gov/ Statistics_by_State/Oregon/Publications/Field_ Crop_Report/crop\%20reports/01_13an.pdf>.
SAS Institute Inc. 2010. SAS/STAT ${ }^{\circledR} 9.3$ user's guide. SAS Institute Inc., Cary, NC.

Sokovic, M.D., J. Vukojevic, P.D. Marin, D.D. Brkic, V. Vajs, and L.J.L.D. van Griensven. 2009. Chemical composition of essential oils of Thymus and Mentha species and their antifungal activities. Molecules 14:238-249.

Topalov, V.D. 1989. Mentha, p. 372-381. In: Topalov, V.D., I.I. Dechev, and M.S. Pehlivanov (eds.). Plant production. Zemizdat Press, Sofia, Bulgaria.

Zheljazkov, V.D., T. Astatkie, and E.A. Jeliazkova 2013. Effect of foliar application of methyl jasmonate and extracts of juniper and sagebrush on essential oil yield and composition of 'Native' spearmint. HortScience 48:462 465.

Zheljazkov, V.D., C.L. Cantrell, T. Astatkie, and M.W. Ebelhar. 2010a. Productivity, oil content and composition of two spearmint species in Mississippi. Agron. J. 102:129-133.

Zheljazkov, V.D., C.L. Cantrell, T. Astatkie, and A. Hristov. 2010b. Yield, content, and composition of peppermint and spearmints as a function of harvesting time and drying. J. Agr. Food Chem. 58:11400-11407.

Zheljazkov, V.D., C.L. Cantrell, T. Astatkie, and E. Jeliazkova. 2012. Fall frosts effects on the essential oil of 'Native' spearmint in Wyoming. HortScience 47:1603-1606. 